\title{
Geochronology and heavy metal flux to Guanabara Bay, Rio de Janeiro state: a preliminary study
}

\author{
JOSÉ A. BAPTISTA NETO ${ }^{1}$, TOMÁS C.S. PEIXOTO ${ }^{1}$, BERNARD J. SMITH ${ }^{2}$, JOHN J. MCALISTER ${ }^{2}$, \\ SORAYA M. PATCHINEELAM ${ }^{1}$, SAMBASIVA R. PATCHINEELAM ${ }^{3}$ and ESTEFAN M. FONSECA ${ }^{1}$ \\ ${ }^{1}$ Departamento de Geologia,Universidade Federal Fluminense, \\ Av. General Milton Tavares de Souza, s/n, Gragoatá, 24210-346 Niterói, RJ, Brasil \\ ${ }^{2}$ School of Geography, Queen's University, Belfast, BT7 1NN, UK \\ ${ }^{3}$ Universidade Federal Fluminense, Departamento de Geoquímica, \\ Outeiro São João Batista, s/n, 24210-346 Niterói, RJ, Brasil
}

Manuscript received on December 31, 2012; accepted for publication on April 3, 2013

\begin{abstract}
Guanabara Bay, located in Rio de Janeiro state. It is surrounded by the second most important metropolitan area of the country. Over recent decades, land disturbance and urbanization in the surrounding area has significantly increased sediment input to the bay and had a negative effect on its overall environmental. This is especially related to high volumes of untreated sewage and industrial effluents. This study evaluates the history of this human impact through detailed examination of a sediment core taken from the northern portion of Guanabara Bay. A geochronology is established using ${ }^{210} \mathrm{~Pb}$ dating and related to organic carbon and heavy metal fluxes to the sediments. This gave a calculated net average sedimentation rate for the core of $0.67 \mathrm{~cm}$.year ${ }^{-1}$. The organic carbon and heavy metals flux started to increase at the beginning of the last century and the highest values was observed in the top of the cores.
\end{abstract}

Key words: ${ }^{210} \mathrm{~Pb}$, geochronology, Flux of heavy metal, Guanabara Bay.

\section{INTRODUCTION}

Estuarine and coastal lagoon sediments provide unique records of the environmental history of a drainage basin, and frequently yield detailed evidence of the changes to catchment dynamics caused by human activities (Arnason and Fletcher 2003, Di Lauro et al. 2004, Sanders et al. 2006). The impacts of anthropogenic changes have greatly accelerated over the last 150 years and have been particularly associated with important transformations in the aquatic environments linked to increased pollution loading resulting from rapid urbanization and the

Correspondence to: José Antonio Baptista Neto

E-mail: jabneto@id.uff.br growth of industrial activities (Ip et al. 2004, Feng et al. 2004). Amongst the most prominent of these pollutants are heavy and trace metals (hereafter grouped as heavy metals) that show a particular affinity for the fine sediments that characterize many nearshore environments and a propensity for long-term persistence within the sediment record (Li et al. 2001, Arnason and Fletcher 2003). As a byproduct of this persistence, vertical concentration profiles of heavy metals in estuarine sediment cores have been used increasingly over the last 30 years as a means of understanding environmental change within contributing catchments (Vaalgamaa 2004). This strategy has been greatly aided by the 
advent of radiometric dating methods, particularly ${ }^{210} \mathrm{~Pb}$ (Marques Jr et al. 2006) that have allowed the construction of geochronologies linked to the sedimentation (e.g. Robbins and Edgington 1975, Oldfield and Appleby 1984, Sharma et al. 1987, Simões Filho 1993, Turner and Delorme 1996, Godoy et al. 1998, Patchineelam et al. 1999, Di Lauro et al. 2004, Sanders et al. 2006). Since the introduction of ${ }^{210} \mathrm{~Pb}$ dating for sediments by Goldberg (1963) it has been widely applied to lakes, estuaries and coastal marine environments as a geochronological tool (Appleby and Oldfield 1992, Matsumoto 1975, 1987, Robbins and Edgington 1975, Robbins and Herche 1993, Smith 2001, Lu and Matsumoto 2005). The natural radionuclide of ${ }^{210} \mathrm{~Pb}\left(T^{1} / 2=22.26 \mathrm{yr}\right)$ is a byproduct of ${ }^{226} \mathrm{Ra}$ decay (Ruiz-Fernández and Hillaire-Marcel 2009) and is supplied to the aquatic environment by atmospheric deposition, although it can also result from the decay of dissolved ${ }^{226} \mathrm{Ra}$ in the open ocean (where production of ${ }^{210} \mathrm{~Pb}$ from ${ }^{226} \mathrm{Ra}$ can exceed the atmospheric ${ }^{210} \mathrm{~Pb}$ contribution by factors of 2-20; Cochran 1992). Because of its relatively short half-life, ${ }^{210} \mathrm{~Pb}$ has been shown to be an ideal tracer for dating aquatic sediments deposited during the last 100 years, a period of time during which appreciable environmental changes have occurred due to urbanization and industrialization. However, there has been very little research into recent metal fluxes to the bay. In order to address this gap in knowledge and to estimate the magnitude of heavy metal fluxes to the sediments of Guanabara Bay, the present study aims to assess the fluxes of key metals ( $\mathrm{Zn}, \mathrm{Pb}, \mathrm{Cu}, \mathrm{Cr}$ and $\mathrm{Ni}$ ) into Guanabara Bay through an examination of their concentration in a dated sediment core using chemical and ${ }^{210} \mathrm{~Pb}$ analyses. The results will be used to evaluate the anthropogenic inputs of metals into the sediments of Guanabara Bay over time, particularly the past 50 years of rapid economic development.

Besides the huge environmental pollution in Guanabara Bay, the studied area is one of the main protected area in this bay, with the lower heavy metal concentrations (Baptista Neto et al. 2006). However, the catchment of the rivers that flows to this region will receive a huge petrochemical complex, already under construction, which will increase the amount of heavy metal and sediments to the studied area, making this baseline data extremely important, concerning the future of this area.

In the last 100 years the catchment area around Guanabara Bay has been strongly modified by human activities, in particular deforestation and uncontrolled settlement, which have generally increased river discharges and sediment loads flowing into the bay. Consequently the average rates of sedimentation are thought to have increased to $1-2 \mathrm{~cm}$ year $^{-1}$ (Godoy et al. 1998), although this figure has yet to be substantiated.

\section{STUDY AREA}

Guanabara Bay (Figure 1) lies entirely within Rio de Janeiro State, Southeast Brazil between $22^{\circ} 40^{\prime}$ $-23^{\circ} 00^{\prime} \mathrm{S}$ and $43^{\circ} 00^{\prime}-43^{\circ} 18^{\prime} \mathrm{W}$. It is one of the largest bays on the Brazilian coastline and covers an area of approximately $384 \mathrm{~km}^{2}$, including a number of islands. According to Amador (1997) the coastline of the bay is $131 \mathrm{~km}$ long; the mean water volume is $1.871,09 \mathrm{~m}^{3}$, measures $28 \mathrm{~km}$ from west to east and $30 \mathrm{~km}$ from south to north and is constrained by a narrow entrance that is only $1.6 \mathrm{~km}$ wide (Kjerfve et al. 1997). The bay has a complex bathymetry with a marked central channel that is some $400 \mathrm{~m}$ wide, stretches more than $5 \mathrm{~km}$ into the bay from the mouth, and is defined by the $30 \mathrm{~m}$ isobath. The deepest point of the bay measures 58 $\mathrm{m}$ and is located within this channel (Kjerfve et al. 1997). According to the same authors, north of the Rio de Janeiro-Niterói bridge, the channel loses its characteristics as the bay rapidly becomes shallower, with an average depth of $5.7 \mathrm{~m}$, due in the main to high rates of sedimentation that have accelerated over the last century in response to human activity in the catchment area. The climate is humid subtropical with a mean annual temperature between 
$20^{\circ} \mathrm{C}$ to $25^{\circ} \mathrm{C}$ and an annual rainfall of $2,500 \mathrm{~mm}$ at higher altitudes and $1,500 \mathrm{~mm}$ at lower altitudes between December and April. (Nimer 1989).

Guanabara Bay is one of the most prominent coastal bays in Brazil. The bay is in reality an estuary of 91 rivers and channels, surrounded by the cities of Rio de Janeiro, Duque de Caxias, São Gonçalo, Niterói and many other small cities and villages. The rapid urbanization and industrialization in the Guanabara Bay region since the 1950s has resulted in

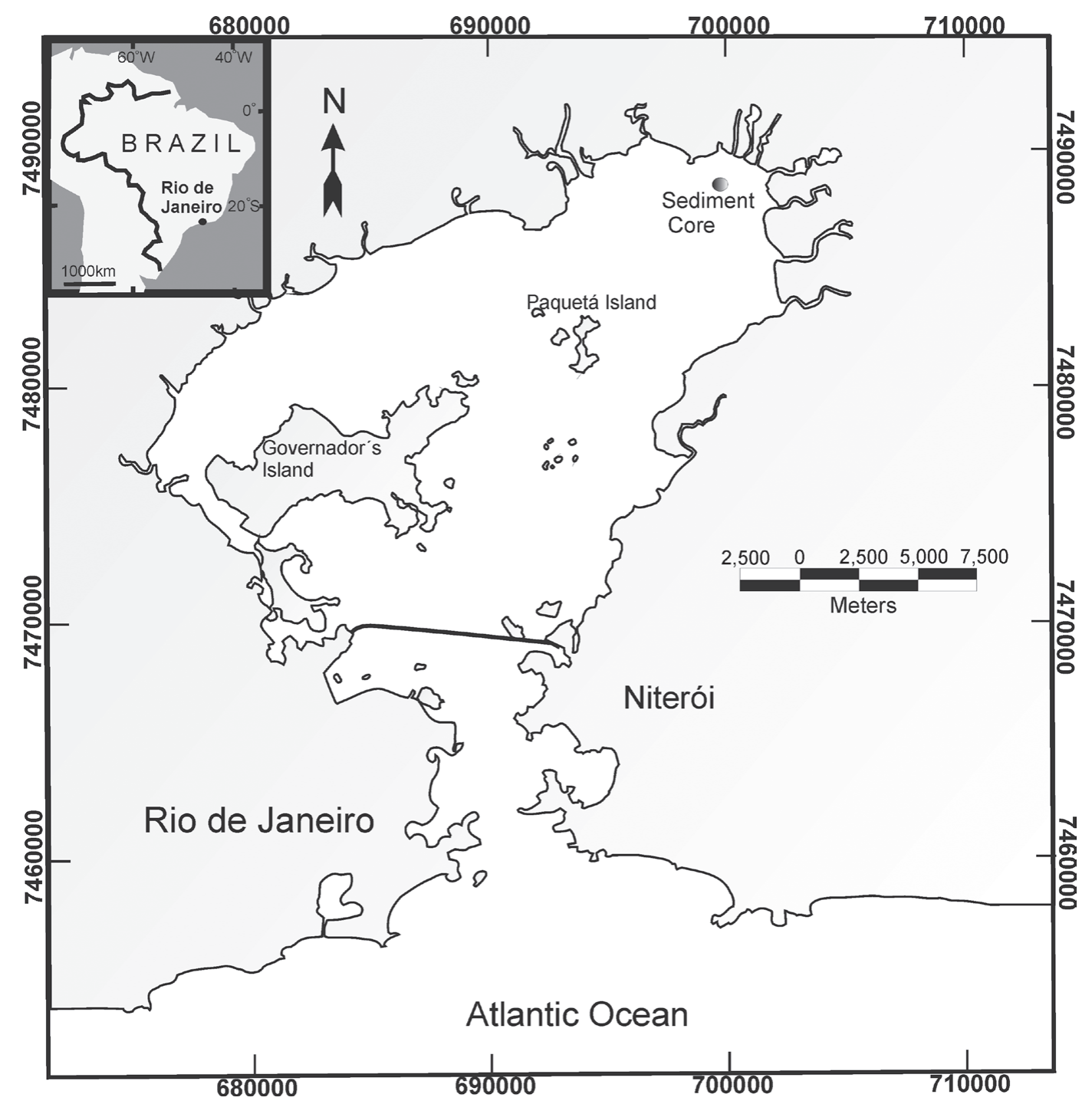

Figure 1 - Map of the location of the studied area.

growing pressure on the local environment (Amador 1997). This has lead to increased contamination of the bay from the combined inputs of the numerous rivers containing untreated sewage effluent, industrial discharges, urban and agricultural runoff, atmospheric fallout, all of which has had a significant impact on the aquatic environment (Rebello et al. 1986,
Baptista Neto et al. 2006, Carreira et al. 2002, McAlister et al. 2000, 2005). The bay also hosts two airports, holds one of the country's main naval bases and is crossed by a $12 \mathrm{~km}$ long bridge used by thousands of cars daily. Previous studies of heavy metal pollution in Guanabara Bay have pointed out that the bay is one of the most polluted ecosystems 
in Brazil (Rebello et al. 1986, Vandenberg and Rebello 1986, Leal and Rebello 1993, Barrocas and Wasserman 1993, Baptista Neto et al. 2000, 2006, Faria and Sanchez 2001, Machado et al. 2002, Carreira et al. 2002, Kehrig et al. 2003, Vilela et al. 2004). Included amongst these assessments are a number of studies that have examined the spatial distribution of heavy metals and organic contaminants in recent sediments of Guanabara Bay (Rebello et al. 1986, Vandenberg and Rebello 1986, Leal and Rebello 1993, Barrocas and Wasserman 1993, Baptista Neto et al. 2000, 2006).

\section{MATERIALS AND METHODS}

This study examines a sediment core $7 \mathrm{~cm}$ in diameter and $180 \mathrm{~cm}$ deep collected in the north of Guanabara Bay close to a mangrove system and a protected environmental area in approximately onemeter of water. After drying at air temperature, the core was split longitudinally and described. One half was sampled by collecting slices at $2 \mathrm{~cm}$ intervals down to a depth of $40 \mathrm{~cm}$ for ${ }^{210} \mathrm{~Pb}$ analyses that employed gamma-ray spectrometry. The other half was sampled in a similar manner along the complete length of the core for particle size, organic carbon and elemental analyses. The sediment core was collected closer to an environmental protected area (APA) of Guapimirim, in order to avoid the most polluted and disturbed area of Guanabara Bay. This area was chose after an analyze of a seismic profile to certify that the area was not disturbed by anthropogenic activity.

Particle size analysis was carried out using a Malvern Mastersizer Microplus, MAF 5001. The water content and porosity of the core were measured based in the methodology proposed by Durham and Joshi (1980). Gamma-ray measurements were made using a semi-planar intrinsic germanium high purity coaxial detector with $40 \%$ efficiency. This was housed in a lead shield and coupled to a multichannel analyzer. Activity was calculated according to wellestablished methods (Patchineelam and Smoak 1999). The sedimentation rate was calculated by dividing the ${ }^{210} \mathrm{~Pb}$ decay constant by the slope of the log-linear plot of unsupported ${ }^{210} \mathrm{~Pb}$ versus depth (Appleby and Oldfield 1992). Total organic carbon was determined using a CS infrared analyser model Eltra Metalyt 1000CS. Sub-samples for chemical analysis were oven dried between 30 $35^{\circ} \mathrm{C}$ since extractable metals were examined and passed through a $2 \mathrm{~mm}$ diameter nylon mesh sieve (Hesse 1971). The $<63 \mu \mathrm{m}$ fraction was collected by further sieving a representative portion of the $<2$ $\mathrm{mm}$ fraction through a nylon mesh. This size fraction was analysed as it is relatively undiluted by coarser sizes and allows a more accurate prediction of the threat to an ecosystem by heavy metals (Forstner and Whittmann 1983). Samples were digested in aqua regia under pressure using a Perkin Elmer microwave digestion system (USEPA 3051a). Sample blanks and a reference sediment WQB-1 from the National Laboratory for Environmental Testing, Burlington, Canada, was also analysed at regular intervals to monitor quality control. Sample extracts were filtered through Whatman No. 40 filter papers into acid washed high-density polyethylene (HDPE) containers and diluted to a volume of 25 $\mathrm{mL}$ in deionised water. Analytical standards were prepared by diluting a 1,000 mg. $\mathrm{L}^{-1} \mathrm{BDH}$ stock solution that is traceable to the NIST Certified Reference Institute. Elemental analysis $(\mathrm{Pb}, \mathrm{Zn}, \mathrm{Ni}$, $\mathrm{Cr}, \mathrm{Cu}, \mathrm{Mn}, \mathrm{Fe}$ ) was carried out using a Perkin Elmer Analyst 200 atomic absorption spectrophotometer.

Sedimentation, compaction and the rate of accumulation of elements within the sediment per unit of area are constant and the rate of time is given by the formula

$$
T=\varpi \times \rho_{s}(1-\phi) \times C \times 10^{4}
$$

where: $\mathrm{T}$ is the burial rate $\left(\mathrm{mg} \cdot \mathrm{m}^{-2} \cdot \mathrm{year}^{-1}\right)$; $\omega$ is the sedimentation rates $\left(\mathrm{cm}\right.$ year $\left.^{-1}\right)$; $\rho$ s is the mean density of solids $\left(\mathrm{g} \cdot \mathrm{cm}^{-3}\right)$; $\varnothing$ is the porosity; $\mathrm{C}$ is the concentration of the element in the sediment $\left(\mathrm{mg}^{-\mathrm{g}^{-1}}\right)$; and 104 is the factor for conversion of $\mathrm{cm}^{-2}$ to $\mathrm{m}^{-2}$. (Berner 1980). 


\section{RESULTS AND DISCUSSION}

Pollution is a negative outcome of rapid development and industrialization. Marine bays adjacent to metropolitan areas are strongly polluted by domestic, industrial and other sources of waste and anthropogenic impacts have seriously influenced the whole marine ecosystem. Heavy metals are produced from a variety of natural and anthropogenic sources, for example, metal pollution can result from direct atmospheric deposition, geologic weathering or through the discharge of agricultural, municipal, residential or industrial waste products (Demirak et al. 2006).

Heavy metal analysis in estuarine sediment cores has become popular in the study of environmental change over the past 40 years (Audry et al. 2004, Cochran et al. 1998). According to Farmer et al. (1996) and Ip et al. (2004) the increase in metal concentrations within sediment cores is considered as being due to temporal variations in atmospheric deposition, catchment runoff, effluent inflow and dumping of waste from various human activities. In the absence of long-term monitoring data, the sedimentary record can be used to provide retrospective information on the past characteristics of a coastal environment.

Heavy metals and other pollutants are adsorbed onto fine particle surfaces of sediments since they have a very high specific surface area, therefore scavenging by suspended particulate matter and subsequent sedimentation creates a repository that provides valuable historical information on the temporal trend of input from pollutants into aquatic ecosystems (Goldberg et al. 1977). If there is a valid accumulation rate these records can provide specific data about rates of sediment accumulation and the anthropogenic flux of pollutants (Axelsson and ElDaoushy 1989). According to Sanchez-Cabeza and Druffel (2009), under certain conditions, sediments provide a reliable record of pollution levels and an indication of the state of an ecosystem. For this to be possible, however, an accurate chronology such as that provided by linked ${ }^{210} \mathrm{~Pb}$ dating is essential.

The percentage of fine sediment increased from a depth of $80 \mathrm{~cm}$ to the top of the core and varied between $50 \%$ to $90 \%$ throughout (Figure 2). Since the porosity of the core was fairly constant throughout, a correction for compaction was not required. The sedimentation rate calculated for the analyzed core through the CIC model was $0.67 \mathrm{~cm}_{\text {.year }}{ }^{-1}$. This value is within the same range as that calculated in the first $40 \mathrm{~cm}$ of a core taken from the same area of Guanabara Bay using a CRS model which measuring ${ }^{210}$ Bi decay (Godoy et al. 1998) (Figure 3). This calculated sedimentary rate can be considered high when compared to other less impacted environments in the Rio de Janeiro State, such as the Guarapina lagoon, where the calculated sedimentary rate was 0.27 cm.year $^{-1}$ (Peixoto et al. 2005). In Sepetiba Bay, another impacted environment close to the study area, the estimated sedimentary rate was $0.65 \mathrm{~cm}$ year $^{-1}$ (Oliveira 2005). However, Guanabara Bay is now considered as one of the most polluted and impacted bays along the Brazilian Coastline.

The increase in fine sediments from a depth of $80 \mathrm{~cm}$ to the top of the core (Figure 2), corresponds to ${ }^{210} \mathrm{~Pb}$ dating of 54 years ago and a sedimentation rate around $0.67 \mathrm{~cm}$.year ${ }^{-1}$. According to Pagliosa et al. (2006) an industrial expansion in Brazil in the mid-1950s promoted rapid urban growth that took place mainly around coastal areas. Urban sprawl has caused changes in the physical, chemical and biological characteristics of estuarine systems (Ridgway and Shimmield 2002). Increase in the amount of sediment entering Guanabara Bay is not only due to an increase in catchment erosion, but also to littoral modifications that is a direct result of land reclamation (Amador 1997).

Organic carbon flux was calculated by using a value of $2.5 \mathrm{~g} . \mathrm{cm}^{-3}$ to represent the average density of the dry solid. Results show a significant increase in organic carbon flux where a value of 76 g.C.m ${ }^{-2}$. year $^{-1}$ at the beginning of the century reached a value 


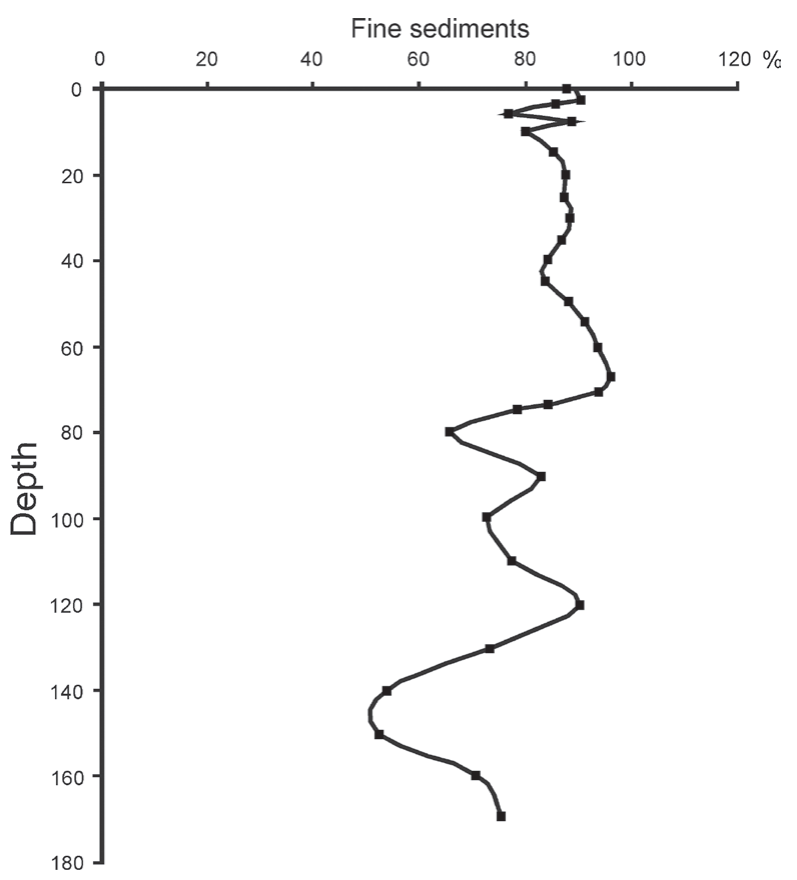

Figure 2 - Percentage of fine sediments in sediment core.

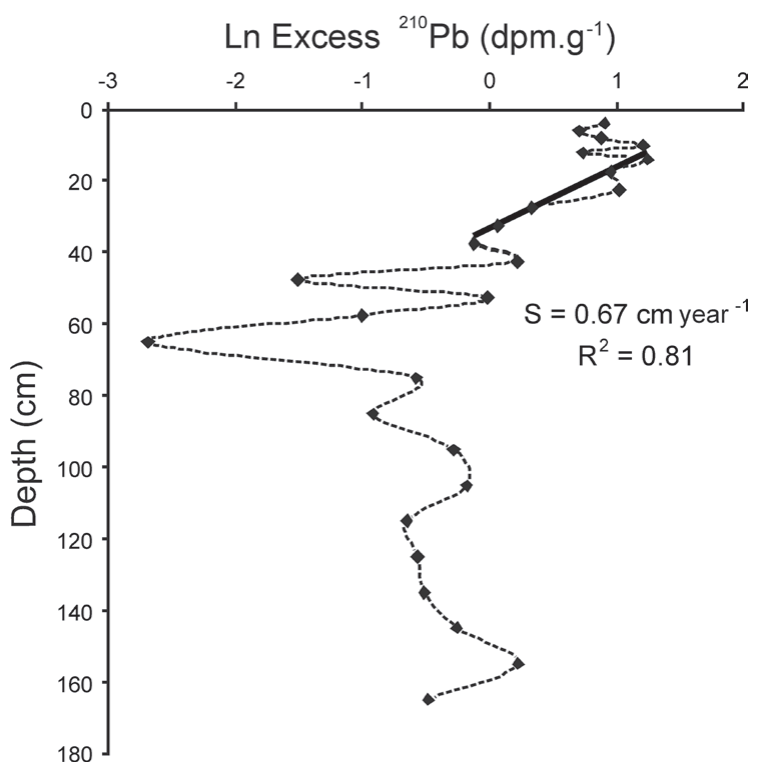

Figure 3 - Profile the Ln excess activity ${ }^{210} \mathrm{~Pb}$ and the rates of sedimentation calculated for the sediment core.

of 370 g.C. $\mathrm{m}^{-2} \cdot$ year $^{-1}$ in the most recent sediment layers (Figure 4). Compared to other studies carried out in various other environments, Guanabara Bay shows higher organic flux values (Table I).

Carreira (2000) found a similar pattern for organic carbon flux in recent sediments from

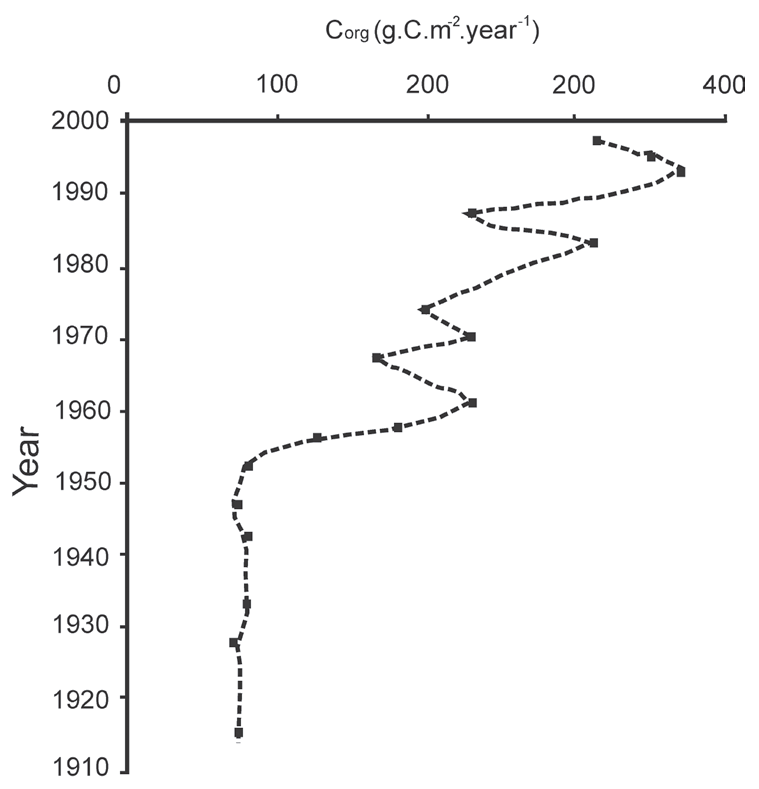

Figure 4 - Flux of organic carbon in the sediment core.

TABLE I

Flux of organic carbon in sediments from different environment all over the world.

\begin{tabular}{|c|c|c|}
\hline Author & Local & $\begin{array}{l}\text { Flux of Org } \\
\left(\mathrm{g} \cdot \mathrm{m}^{-2} \cdot \mathrm{year}^{-1}\right)\end{array}$ \\
\hline This study & Guanabara Bay, RJ & $76-370$ \\
\hline Carreira 2000 & Guanabara Bay, RJ & $22-272$ \\
\hline $\begin{array}{l}\text { Twilley } 1992 \\
\text { apud Alongi et } \\
\text { al. } 2001\end{array}$ & $\begin{array}{l}\text { Mangroves from } \\
\text { several countries. }\end{array}$ & 99.7 \\
\hline $\begin{array}{c}\text { Zimmerman and } \\
\text { Canuel } 2000\end{array}$ & $\begin{array}{c}\text { ChesaPeake Bay, } \\
\text { EUA }\end{array}$ & $\begin{array}{c}46-165 \\
\text { (estimate) }\end{array}$ \\
\hline $\begin{array}{l}\text { Alongi et al. } \\
2001\end{array}$ & South of Thailand & $183-281$ \\
\hline $\begin{array}{l}\text { Brunskill et al. } \\
2002\end{array}$ & $\begin{array}{c}\text { Herbert River, } \\
\text { Australia }\end{array}$ & $26-336$ \\
\hline $\begin{array}{c}\text { Gordon and Goñi } \\
2004\end{array}$ & $\begin{array}{c}\text { Mississipi Delta, } \\
\text { EUA }\end{array}$ & 54 \\
\hline
\end{tabular}

Guanabara Bay. A core collected from an area close to the present study, showed an organic carbon flux ranging from 22 g.C.m ${ }^{-2}$.year ${ }^{-1}$ to 272 g.C.m ${ }^{-2}$. year $^{-1}$. These values are lower than those found in the present study, however, the same author found values of 500 g.C.m $\mathrm{m}^{-2}$.year ${ }^{-1}$ in others areas of Guanabara Bay, confirming an increase in organic matter and eutrophication within the bay. 
Several studies with respect to heavy metals and organic carbon concentrations in sediment cores collected from the Brazilian coastline have already been carried out. However, very few studies have examined the flux of heavy metals in these environments. Therefore this combination of ${ }^{210} \mathrm{~Pb}$ dating and heavy metal analysis provides a better understanding and a useful historical record of the heavy metal fluxes within Guanabara Bay.

TABLE II

Flux of heavy metal to Guanabara Bay in different periods.

\begin{tabular}{|c|c|c|c|c|c|}
\hline & Zn $\left(\right.$ g.Zn.m. ${ }^{-2} \cdot$ year $\left.^{-1}\right)$ & $\mathrm{Ni}\left(\right.$ g.Ni.m ${ }^{-2} \cdot$ year $\left.^{-1}\right)$ & $\mathrm{Cr}\left(\right.$ g.Cr.m ${ }^{-2} \cdot$ year $\left.^{-1}\right)$ & $\mathrm{Cu}\left(\right.$ g.Cu. $\mathrm{m}^{-2} \cdot$ year $\left.^{-1}\right)$ & $\mathrm{Pb}\left(\mathrm{g} \cdot \mathrm{Pb} \cdot \mathrm{m}^{-2} \cdot \mathrm{year}^{-1}\right)$ \\
\hline 1997 & 670.0 & 318.2 & 318.2 & 142.7 & 2629.7 \\
\hline 1950 & 366.4 & 232.0 & 201.5 & 55.0 & 189.3 \\
\hline 1900 & 275.1 & 242.1 & 187.1 & 77.0 & 209.1 \\
\hline
\end{tabular}

Table II shows all the metal concentrations throughout the core profile and figure 5 shows the heavy metal flux. Cr concentrations range from $21.25 \mathrm{ppm}$ to $47.5 \mathrm{ppm}$, with an average of 39.4 ppm, the Cr flux to the sediment range from 187.1 to 318.2 g.Cr.m ${ }^{-2}$.year ${ }^{-1}$. Cu concentrations range from $8.7 \mathrm{ppm}$ to $23.7 \mathrm{ppm}$ with an average $17 \mathrm{ppm}$, the $\mathrm{Cu}$ flux to the sediment range from 73.1 to 142.7 g.Cu. $\mathrm{m}^{-2}$.year ${ }^{-1}$. Zn ranges from $31.2 \mathrm{pm}$ to 112.5 ppm with an average of $79.7 \mathrm{ppm}$, the $\mathrm{Zn}$ flux to the sediment range from 275.01 to 669.9 g.Zn.m ${ }^{-2}$. year $^{-1}$. $\mathrm{Pb}$ is from 21.2 to $397.5 \mathrm{ppm}$ with an average $68.8 \mathrm{ppm}$, the $\mathrm{Pb}$ flux to the sediment range from 183.6 to $2,629.7$ g.Pb.m ${ }^{-2}$.year ${ }^{-1}$ and Ni ranges from $27.5 \mathrm{ppm}$ to $53.7 \mathrm{ppm}$ with an average of $45.7 \mathrm{ppm}$, the Ni flux to the sediment range from 227 to 318 g.Ni.m ${ }^{-2}$.year ${ }^{-1}$. Results show that most of the metals increase from the bottom to the top of the core, i.e. from the past to the present. Lead, $\mathrm{Cu}$ and $\mathrm{Zn}$ show fluctuating concentrations with an increasing pattern, where subsurface sediments record the highest values. A decrease in their concentrations occurs at the top of the core implying that the flux of these metals have progressively increased with time, but have reduced in concentration over recent years due to the more stringent rules that have been applied in an attempt to reduce toxic air emissions.

Significant increases in heavy metals in the upper part of the core, after the 1950's, correspond to urbanization and industrialization processes during this period. Heavy metal accumulations prior to 1950 (Figure 5) may be linked to the deforestation that occurred in the area during this period. Lead, $\mathrm{Zn}, \mathrm{Cr}, \mathrm{Ni}$ and $\mathrm{Cu}$ concentrations in the core profile are presented in Figure 5. The highest concentrations were observed in the upper part of the core 1997, in the modern time, which correspond the increased amount of the sewage input in the bay (Table II). The increases in $\mathrm{Zn}, \mathrm{Cu}$ and $\mathrm{Pb}$ concentrations in the surface sediments of Guanabara Bay have been reported in previous studies (Rebello et al. 1986, Vandenberg and Rebello 1986, Leal and Rebello 1993, Baptista Neto et al. 2000, 2006, Faria and Sanches 2001, Machado et al. 2002). In the present study, however, it is interesting to note that increases in the concentrations of $\mathrm{Pb}, \mathrm{Cu}$, $\mathrm{Cr}, \mathrm{Ni}$ and $\mathrm{Zn}$ in this core all appear before the recent period (from the 1950s). These accumulations could be attributed to increased inputs from natural erosion derived from the rapid deforestation carried out in this area during the colonial period followed by the rapid industrial development and urbanisation in the last few decades, mainly from 1959. These accumulations in $\mathrm{Pb}, \mathrm{Cu}, \mathrm{Cr}$, Ni and $\mathrm{Zn}$ concentrations after the 1950s correspond to the increase in urban activities that occurred over this period of time. Point-source inputs of these elements to aquatic environments include industrial effluents, municipal wastewaters, emissions from smelting operations and fossil fuel 
combustion. Today much of the anthropogenic $\mathrm{Zn}$ is derived from fossil fuel combustion (Nriagu and Davidson 1980) and automobile tire wear (Callender and Rice 2000). Copper originates from smelters, fossil fuel uses, industrial discharges, agriculture, mining and wastewaters, and mainly by untreated sewage (Valette-Silver 1992). Pb content increased in recent layers is due probably as consequence of the gas emission from vehicles that
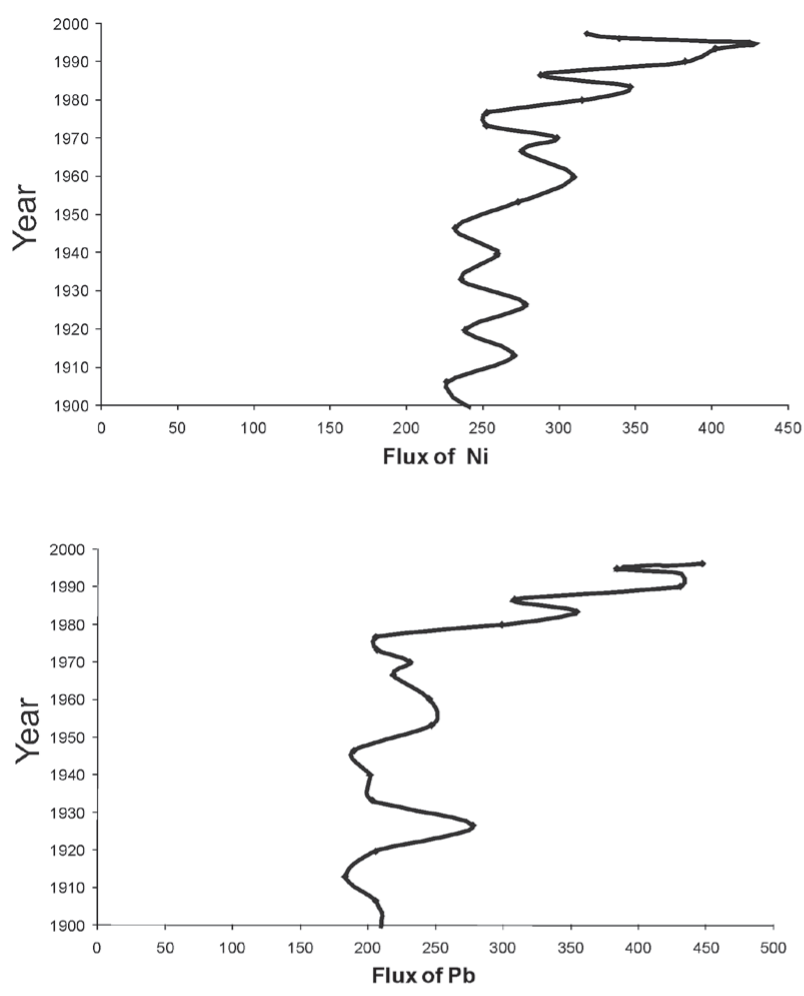

employed gasoline containing anti-knock based in lead, during several years. The bridge over the bay favours its subsequent transfer to the bay's water, and the increased concentrations of $\mathrm{Ni}$ and $\mathrm{Cr}$ are also related with the polluted wastes dumped by the industrial and urban activities in the zone. Analysis of this sediment core from Guanabara Bay reflects a trend of increasing metal concentrations, that started in the 1950s (Baptista Neto et al. 1999).
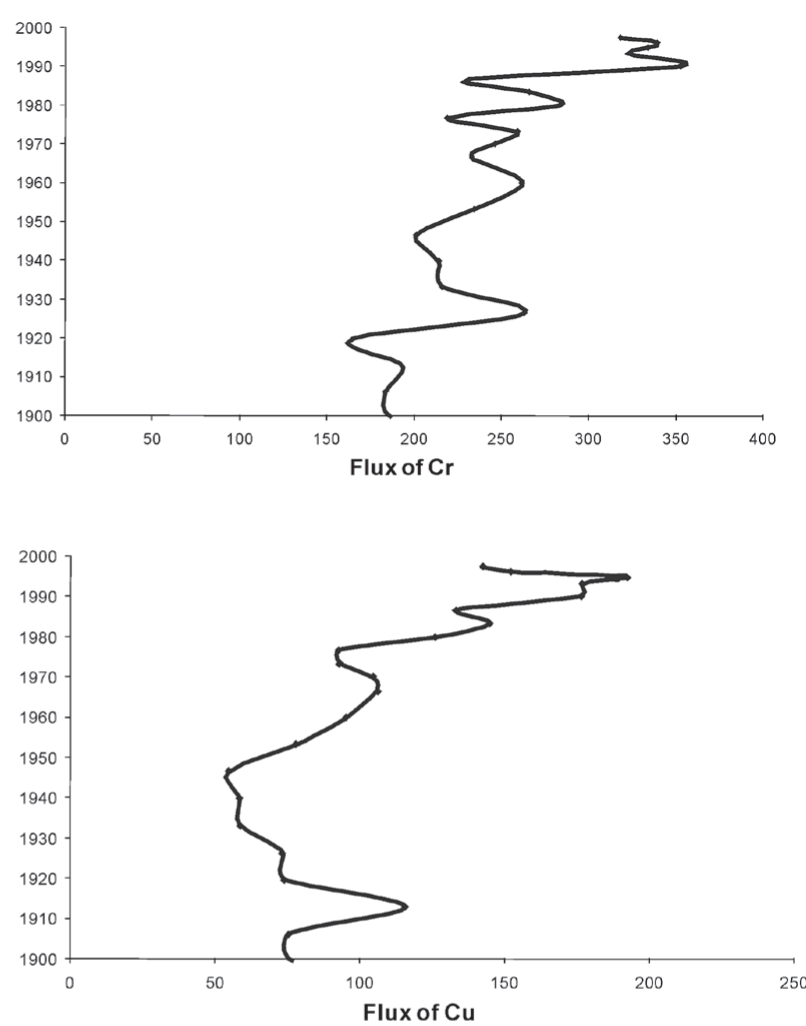

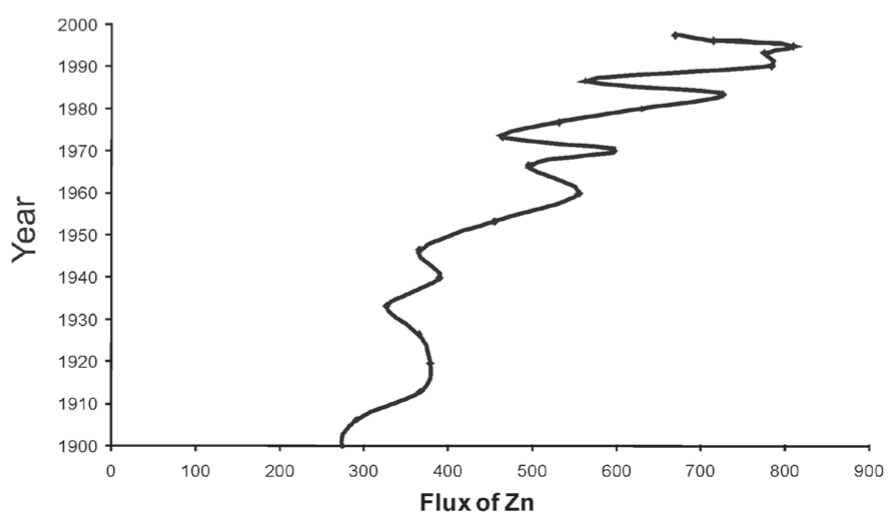

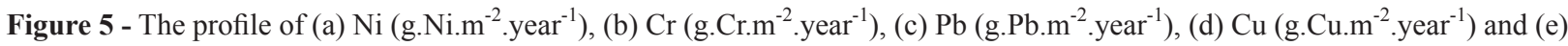
$\mathrm{Zn}\left(\mathrm{g} \cdot \mathrm{Zn} \cdot \mathrm{m}^{-2}\right.$.year $\left.{ }^{-1}\right)$ concentrations over time in the sediment core. 


\section{CONCLUSIONS}

Results from this study highlights the importance of combining both heavy metal and $\mathrm{Pb}^{210}$ analyses to examine the flux of heavy metals into Guanabara Bay and the environmental changes over a period of time.

A value of $0.67 \mathrm{~cm}$.year ${ }^{-1}$ for the sedimentation rate in Guanabara Bay would indicate the level of human impact in the sediment cycle within the Bay, since this rates is very high compared to other less impacted environment in SE of Brazil.

The concentration of heavy metals shows a constant increased over the last 50 years, with the highest levels in the top layer of the core. This time period is related to an increase of urbanization (post1950) and deforestation (pre-1950) in the catchment area. The same pattern was also observed for the organic carbon flux, which could indicate the recent impact of the untreated sewage dumping into the bay.

Guanabara Bay is a very heterogeneous environment, therefore, more sediment cores should be taken from various other regions within the bay in order to understand the flux of heavy metal into this water body. The studied area was always considered as a nonimpacted area of the bay, been considered a "clean" zone inside the bay. However, these preliminary results highlight the extent of the environmental degradation experienced in Guanabara Bay as a whole in the last few decades. These results also correlated with data from other research that have also considered Guanabara Bay to be one of the most impacted coastal environments in Brazil.

\section{ACKNOWLEDGMENTS}

This work was supported financially by Conselho Nacional de Desenvolvimento Científico e Tecnológico (CNPq)/Brazil.

\section{RESUMO}

A Baía de Guanabara, localizada no estado do Rio de Janeiro, é cercada pela segunda mais importante área metropolitana do país. Nas últimas décadas, a urbanização e outros processos na área circundante têm aumentado significativamente a entrada de sedimentos para a baía, tendo um efeito negativo sobre todo o meio ambiente. Estes impactos negativos estão relacionados com grandes volumes de esgoto sem tratamento e efluentes industriais. O presente estudo avalia a história deste impacto humano através do exame detalhado de um testemunho coletado na porção norte da Baía de Guanabara. A geocronologia é estabelecida usando ${ }^{210} \mathrm{~Pb}$ e relacionada com o carbono orgânico e fluxos de metais pesados para os sedimentos. Os resultados indicaram uma taxa de sedimentação média de $0,67 \mathrm{~cm} \cdot \mathrm{y}^{-1}$. O fluxo de carbono orgânico e metais pesados começaram a aumentar no início do século passado e os maiores valores foram observados no topo do testemunho.

Palavras-chave: ${ }^{210} \mathrm{~Pb}$, geocronologia, Fluxo de metais pesados, Baía de Guanabara.

\section{REFERENCES}

Alongi DM, Wattayakorn G, Pfitzner J, Tirendi F, ZAGORSKIS I, BRUNSKILl GJ, DAVIDSON A AND ClOUGH BF. 2001. Organic carbon accumulation and metabolic pathways in sediments of mangrove forests in southern Thailand. Mari Geol 179: 85-73.

AMADOR ES. 1997. Baía de Guanabara e ecossistemas periféricos - Homem e Natureza. Rio de Janeiro, Retroarte Gráfica e Editora, 539 p.

ApPLEBY PG AND OLDFIELD F. 1992. Application of lead-210 to sedimentation studies. In: Ivanovich $\mathrm{M}$ and Harmon RS (Eds), Uranium Series Disequilibrium: Applications to Environmental Problems. $2^{\text {nd }}$ ed., Clarendon Press, $p$. 731-778.

ARNASON JG AND FLETCHER BA. 2003. A 40+ year record of $\mathrm{Cd}, \mathrm{Hg}, \mathrm{Pb}$, and $\mathrm{U}$ deposition in sediments of Patroon Reservoir, Albany County, NY, USA. Environ Poll 123: 383-391.

AUdRY S, SchÄFER J, BlanC G AND JOUANNEAU JM. 2004. Fifty-year sedimentary record of heavy-metal pollution $(\mathrm{Cd}, \mathrm{Zn}, \mathrm{Cu}, \mathrm{Pb})$ in Lot River reservoirs (France). Environ Poll 132: 413-426.

AXELSSON V AND EL-DaOUshy F. 1989. Sedimentation in the Edsviken bay studied by the X-ray and the $\mathrm{Pb}-210$ methods. Geog An 71A(1-2): 87-93.

Baptista Neto JA, Gingele FX, Leipe T And BRehme I. 2006. Spatial distribution of trace elements in surficial sediments from Guanabara Bay - Rio de Janeiro/Brazil. Environ Geol 49: 1051-1063.

BAptista Neto JA, Smith BJ AND MCAlister JJ. 1999. Sedimentological evidence of human impact on a nearshore environment: Jurujuba Sound, Rio de Janeiro State, Brazil. Appl Geog 19(2): 153-177. 
BAptista Neto JA, Smith BJ AND MCAlister JJ. 2000. Heavy metal concentrations in surface sediments in a nearshore environment, Jurujuba Sound, SE Brazil. Environ Poll 109(1): 1-9.

BARROCAS PR AND WASSERMAN JC. 1993. O mercúrio na Baía de Guanabara: um revisão histórica. Programa de Pósgraduação em Geoquímica, UFF, Niterói, RJ, p. 115-127.

BERNER RA. 1980. Early diagenesis: a theoretical approach. Princeton, Princeton University Press, $241 \mathrm{p}$.

Brunskill GJ, Zagorskis I AND PFitZner J. 2002. Carbon burial rates in sediments and a carbon mass balance for the Herbert River region of the Great Barrier Reef continental shelf, North Queensland, Australia. Estuar Coast Shelf Sci 54: 677-700.

CALlender E AND RiCE KC. 2000. The urban environmental gradient: anthropogenic influences on the spatial and temporal distributions of lead and zinc in sediments. Environ Sci Tech 2: 232-238.

CARREIRA RS. 2000. Investigação Sobre o Acréscimo da Estocagem de Carbono em Ambientes Fertilizados pela Ação Antropogênica: a Baía de Guanabara como modelo. $\mathrm{PhD}$ thesis. Departamento de Química, PUC-Rio, Rio de Janeiro, RJ, 215 p.

CARreira RS, Rebello AHL, REAdMAN JWF, Tim W, MACKO AS AND VeIgA A. 2002. Changes in the sedimentary organic carbon pool of a fertilized tropical estuary, Guanabara Bay, Brazil: an elemental, isotopic and molecular marker approach. Mar Chem 79: 207-227.

COCHRAN JK. 1992. The oceanic chemistry of the uraniumand thorium-series nuclides. In: Ivanovich $\mathrm{M}$ and Harmon RS (Eds), Uranium-Series Disequilibrium: Applications to Earth, Marine and Environmental Sciences. Clarendon Press, Oxford, p. 334-391.

Cochran JK, Frignani M, SALAmanca M, BellucCi LG AND GUERZONI S. 1998. Lead-210 as a tracer of atmospheric input of heavy metals in the northern Venice Lagoon. Mar Chem 62: 15-29.

Demirak A, Yilmaz F, Tuna AL AND OZdemir N. 2006. Heavy metals in water, sediment and tissues of Leuciscus cephalus from a stream in southwestern Turkey. Chemos 63(9): 1451-1458.

Di Lauro A, Fernex F, Fierro G, Ferrand JL, Pupin JP AND GASPARRO J. 2004. Geochemical approach to the sedimentary evolution of the Bay of Nice (NW Mediterranean Sea). Cont Shelf Res 24: 223-239.

DURHAM RW AND JOSHI SR. 1980. Recent sedimentation rates, ${ }^{210} \mathrm{~Pb}$ fluxes, and particle settling velocities in Lake Huron, Laurentian Great Lakes. Chem Geol 31: 53-66.

FARIA MM AND SANCHEZ BA. 2001. Geochemistry and mineralogy of recent sediments of Guanabara Bay (NE sector) and its major rivers-Rio de Janeiro State-Brazil. An Acad Bras Cienc 73: 121-133.

FARMER JG, EADES LJ, MACKENZIE AB, KIRIKA A AND BAILEY-WATTS TE. 1996. Stable lead isotope record of lead pollution in Loch Lomond sediments since 1630 A.D. Environ Sci Tech 30: 3080-3083.
FENG H, HAN XF, ZHANG WG AND YU LZ. 2004. A preliminary study of heavy metal contamination in Yangtze River intertidal zone due to urbanization. Mar Pol Bul 49: 910-915.

Forstner U AND WitTMAnN GTW. 1983. Metal Pollution in the Aquatic Environment. Springer-Verlag, Berlin, Heidelberg, New York, $436 \mathrm{p}$.

Godoy JM, Moreira I, BragançA MJ, WANDERley C AND MENDES LD. 1998. A study of Guanabara Bay sedimentation rates. J Radioanal Nucl Chem 227(1-2): $157-160$

GOLDBERG ED. 1963. Geochronology with ${ }^{210} \mathrm{~Pb}$. In: Radioactivity Dating. IAEA, Vienna, p. 121-131.

GoldBerg ED, GAMBle E, GRIFFIn JJ AND KoIDE M. 1977. Pollution history of Narragansett Bay as recorded in its sediments. Est Coast Mar Sci 5: 549-561.

GORDON ES AND GoÑI MA. 2004. Controls on the distribution and accumulation of terrigenous organic matter in sediments from the Mississippi and Atchafalaya river margin. Mar Chem 92: 331-352.

HeSSE PR (ED). 1971. A Textbook of Soil Chemical Analysis, London: John Murray, Publishers Ltd., 520 p.

IP CCM, LI XD, ZHANG G, FARMER JG, WAI OWH AND LI YS. 2004. Over one hundred years of trace metal fluxes in the sediments of the Pearl River Estuary, South China. Environ Pol 132: 157-172.

LEAL M AND REBELLO AH. 1993. Remobilization of anthropogenic copper deposited in sediments of a tropical estuary. Chem Spec bioav 24(1): 31-39.

LI XD, SHEN ZG, WAI O AND LI YS. 2001. Chemical forms of $\mathrm{Pb}, \mathrm{Zn}$ and $\mathrm{Cu}$ in the sediment profiles of the Pearl River Estuary. Mar Pol Bul 42: 215-223.

LU X AND Matsumoto E. 2005. Recent sedimentation rates derived from $\mathrm{Pb}-210$ and $\mathrm{Cs}-137$ methods in Ise Bay, Japan. Est Coast Shelf Sci 65: 83-93.

Kehrig HA, Pinto FN, Moreira I and Malm O. 2003. Heavy metals and methylmercury in a tropical coastal estuary and a mangrove in Brazil. Org Geoch 34(5): 661-669.

KJERFVE B, RibeIRO CHA, DiAS GTM, FILIPPO AM AND QUARESMA VS. 1997. Oceanographic characteristics of an impacted costal bay: Baía de Guanabara, Rio de Janeiro, Brazil. Cont Shelf Res 17(13): 1609-1643.

Machado W, Silva-Filho EV, OliveIRA RR AND LACERDA LD. 2002. Trace metal retention in mangrove ecosystems in Guanabara Bay, SE Brazil. Mar Pol Bul 44(11): 1277-1280.

Marques JR AN, Monna F, Silva Filho EV, Fernex F AND SiMÕES FILHO FL. 2006. Apparent discrepancy in contamination history of a subtropical estuary evaluated through ${ }^{210} \mathrm{~Pb}$ profile and chronostatigraphical markers. Mar Pol Bul 52: 532-539.

MATSUMOTO E. 1975. ${ }^{210} \mathrm{~Pb}$ geochronology of sediments from Lake Shinji. Geochem J 9: 167-172.

MATSUMOTO E. 1987. Pb-210 geochronology of sediments, studies of the San'in Region. Nat Environ 3: 187-194. 
McAlister JJ, Smith BJ And Baptista Neto JA. 2000. The Presence of Calcium Oxalate Dihydrate (Weddellite) in Street Sediments from Niterói, Brazil and Its Health Implications. Envir Geoch Heal 22: 195-210.

McAlister JJ, SMith BJ, BAPTista Neto JA AND SimPSON J. 2005. Geochemical distribution and bioavailability of heavy metal and oxalate in street sediments from Rio de Janeiro, Brazil: a preliminary investigation. Environ Geoch Heal 27: 429-441.

NiMER E. 1989. Climatologia do Brasil. Rio de Janeiro: Instituto Brasileiro de Geografia e Estatística (IBGE).

NRIAGU JO AND DAVIDSON CI. 1980. Zinc in the atmosphere. In: Zinc in the Environment. 1: 113-159.

OLDFIELD F AND APPLEBY PG. 1984. A combined radiometric and mineral magnetic approach to recent geochronology in lakes affected by catchment disturbance and sediment redistribution. Chem Geol 44: 67-83.

Oliveira GH. 2005. Estudos de Geocronologia Recente em Sedimentos Costeiros do Estado do Rio de Janeiro. BSc. Dissertation, Departamento de Oceanografia, Universidade do Estado do Rio de Janeiro, 40 p. (Unpublished).

PAGLIOSA PR, FonsECA A AND BARBOSA FAR. 2006. Evidence of systemic changes in trace metal concentrations in subtropical estuarine sediments as a result of urbanization. J Coast Res, Florida - USA SI39: 1078-1083.

Patchineelam SM, KJERFVE B AND GARdener RL. 1999. A preliminary sediment budget for the Winyah Bay estuary, South Carolina, USA. Mar Geol 162: 133-144.

PATCHINEELAM SR AND SMOAK JM. 1999. Sediment accumulation rates along the inner eastern Brazilian continental shelf. Geo-Marine Letters 19: 196-201.

PeiXoto TCS, Oliveira GH AND PATChineelam SR. 2005. Geocronologia recente de uma lagoa costeira alterada, RJ. In: II Congr. Bras. Oceanografia. Vitória. Resumos. Vitória.

Rebello AL, Haekel W, Moreira I, SANTelli R AND SCHRODER F. 1986. The Fate of Heavy Metals in an Estuarine Tropical System. Elsevier Science. Mar Chem 18: 215-225.

RIDGWAY J AND SHIMMIELD G. 2002. Estuaries as repositories of historical contamination and their impact on shelf seas. Estuar Coast Shelf Sci 55: 903-928.

RoBbins JA AND EDGINGTON DN. 1975. Determination of recent sedimentation rates in Lake Michigan using ${ }^{210} \mathrm{~Pb}$ and 137Cs. Geochim. Cosmochim Acta 39: 285-304.

RoBBINS JA AND HERCHE LR. 1993. Models and uncertainty in ${ }^{210} \mathrm{~Pb}$ dating of sediments. Verh Int Ver Limnol 25: 217-222.
RUIZ-FERNÁNDEZ AC AND HILlaire-MARCEL C. 2009. ${ }^{210} \mathrm{~Pb}$-derived ages for the reconstruction of terrestrial contaminant history into the Mexican Pacific coast: Potential and limitations. Mar Poll Bul 59: 134-145.

SANCHEZ-CABEZA J AND DRUFFEL ERM. 2009. Environmental records of anthropogenic impacts on coastal ecosystems: an introduction. Mar Poll Bul 59: 87-90.

SANDERs CJ, SANTOS IR, SilVA-FILHO EV AND PATCHINEELAM SR. 2006. Mercury flux to estuarine sediments, derived from $\mathrm{Pb}-210$ and $\mathrm{Cs}-137$ geochronologies (Guaratuba Bay, Brazil). Mar Poll Bul 52: 1085-1089.

Sharma P, GARDNER LR, MoOre WS AND Bollinger MS. 1987. Sedimentation and bioturbation in a salt marsh as revealed by ${ }^{210} \mathrm{~Pb}, 137 \mathrm{Cs}$ and $7 \mathrm{Be}$ studies. Limnol Oceanogr 32: 313-326.

SimÕES FILHO FFL. 1993. A Hidrodinâmica de Particulados em Planícies de Inundação: Um Estudo Sobre as Taxas de Sedimentação de Lagoas Marginais do Rio Mogi-Guaçú. Estação Ecológica de Jataí (Luiz Antônio - SP). MSc. Dissertation. Universidade de São Carlos. São Carlos, SP, 109 p. (Unpublished).

SMITH JN. 2001. Why should we believe ${ }^{210} \mathrm{~Pb}$ sediment geochronologies?, J Environ Radioac 55: 121-123.

TURNER LJ AND DELORME LD. 1996. Assessment of ${ }^{210} \mathrm{~Pb}$ data from Canadian lakes using the CIC and CRS models. Environ Geol 28: 78-87.

VAALGAMAA S. 2004. The effect of urbanisation on Laajalahti Bay, Helsinki City, as reflected by sediment geochemistry. Mar Poll Bul 48: 650-662.

VALETTE-Silver N. 1992. Historical Reconstruction of Contamination Using Sediment Cores: A Review. NOAA Technical Memorandum NOS/ORCA 65, 44 p.

VANDENBERG C AND REBELlo AH. 1986. Organic-copper interactions in Guanabara Bay, Brazil - an electrochemical study of copper complexation by dissolved organic material in a tropical bay. Sci Total environ 58(1-2): 37-45.

Vilela CG, BATISTA DS, BAPTiSTA Neto JA, CRAPEZ M AND MCALISTER JJ. 2004. Benthonic Foraminifera distribution in a high polluted sediment from Niterói Harbour (Guanabara Bay), Rio de Janeiro, Brazil. An Acad Bras Cienc 76: 1-11.

ZIMMERMAN AR AND CANUEL EA. 2000. A geochemical record of eutrophication and anoxia in Chesapeake Bay sediments: anthropogenic influence on organic matter composition. Mar Chem 69: 117-137. 